\title{
Endoscopical appearances of nonsteroidal anti inflammatory drug (NSAID)- enteropathy
}

\author{
Marcellus Simadibrata ${ }^{*}$, GNJ Tytgat ${ }^{f}$, LA Lesmana $^{\S}$, Daldiyono $^{\S}$, Iwan Ariawan ${ }^{\infty}$
}

\begin{abstract}
Abstrak
Obat anti-inflamasi nonsteroid (OAINS) berhubungan dengan meningkatnya insidens komplikasi tukak gastrointestinal yang mendadak dan menetap. Penelitian ini bertujuan untuk menemukan kelainan-kelainan endoskopik yang ditemukan pada duodenum dan jejunum proksimal karena obat OAINS. Tiga puluh delapan pasien yang mengkonsumsi OAINS untuk penyakit arthritis atau rematiknya dimasukkan dalam penelitian ini. Pemeriksaan gastro-duodeno-jejunoskopi dilakukan dengan alat Olympus PCF-10. Gambaran endoskopik entero-gastropati-OAINS dievaluasi dengan sistim skor. Gambaran enterogastropati-OAINS secara endoskopik terlihat berupa hiperemis, erosi dan tukak. Keluhan diare terjadi pada 7,9\% pasien dan dispepsia terjadi pada 71,1\% pasien. Dari pemeriksaan endoskopi di bulbus duodenum, ditemukan 79\% kasus dengan hiperemis, 39,5\% kasus dengan erosi dan 7,9\% kasus tukak. Di duodenum bagian kedua (pars desendens) ditemukan 28,9\% kasus dengan hiperemis, 15,8\% kasus dengan erosi dan 2,6\% kasus tukak. Di jejunum, ditemukan 7,9\% kasus dengan hiperemis, 2,6\% kasus dengan erosi dan tidak ditemukan tukak. Disimpulkan bahwa kelainan endoskopik terbanyak yang ditemukan pada enteropati-OAINS yaitu hiperemis. Lokasi kelainan enteropati-OAINS tersering yaitu di bulbus duodenum. (Med J Indones 2005; 14: 225-9)
\end{abstract}

\begin{abstract}
Non Steroidal Anti Inflammatory Drugs (NSAID) have been associated with a sudden and sustained rise in the incidence of gastrointestinal ulcer complications. The aim of the study was to reveal the endoscopical abnormalities found in the duodenum \& proximal jejunum due to NSAID. Thirty eight patients taking NSAID for their arthritis or rheumatism were included in this study. Gastro-duodeno-jejunoscopy was done with Olympus PCF-10. The endoscopical appearances of NSAID entero-gastropathy were evaluated with a scoring system. The NSAID-entero-gastropathy appearances were endoscopically seen as hyperemia, erosion and ulcer. From all patient recruited, 7.9\% complaint of diarrhea and $71.1 \%$ complaint of dyspepsia. Endoscopically, in the duodenal bulb we found $79 \%$ cases of hyperemia, 39.5\% cases of erosion and $7.9 \%$ cases of ulcer. In the second part (descending part) of the duodenum we found $28.9 \%$ cases of hyperemia, $15.8 \%$ cases of erosion and $2.6 \%$ case of ulcer. In the jejunum, we found $7.9 \%$ cases of hyperemia, $2.6 \%$ case of erosion and no ulcer. It is concluded that the most frequent abnormal endoscopical appearances in NSAID-enteropathy was hyperemia. The most frequent site of NSAID-enteropathy abnormal findings was in the duodenal bulb. (Med J Indones 2005; 14: 225-9)
\end{abstract}

Keywords: NSAID-enteropathy, endoscopical appearances.

Non-steroidal anti-inflammatory drugs (NSAIDs) are a major cause of morbidity and mortality in the world, probably resulting in 1200 death per annum in the

\footnotetext{
* Division of Gastroenterology Department of Internal Medicine Faculty of Medicine University of Indonesial Cipto Mangunkusumo Hospital, Jakarta, Indonesia

$f$ Department of Gastroenterology and Hepatology Academic Medical Center University of Amsterdam Netherland

$\S$ Division of Hepatology Department of Internal Medicine Faculty of Medicine University of Indonesial Cipto Mangunkusumo Hospital, Jakarta, Indonesia

${ }^{\infty}$ Faculty of Public Health University of Indonesia, Depok, Indonesia
}

UK. ${ }^{1}$ When aspirin was first introduced in 1899 , it became the world's first modern drug, and to date it represents the most succesfull NSAID in the world for treating rheumatism or arthritis. However, Douthwaite and Lintott in 1938 demonstrated the association of aspirin use with mucosal erosion and chronic ulceration of the gastrointestinal tract. ${ }^{2}$ Then, the increasing prescription of the new non-aspirin, non-steroidal anti-inflammatory drugs (NSAIDs) indomethacin and its successors, was also associated with a sudden and sustained rise in the incidence of gastrointestinal ulcer complications. ${ }^{3}$ Overall, NSAIDs increase the risk of ulcer bleeding, perforation, hospitalization, and death of approximately 3-10 fold. ${ }^{4,5}$ The cost of treating 
NSAID-related gastrointestinal adverse effects almost certainly exceeds $\$ 4-8$ billion. ${ }^{7}$

In general, the NSAIDs can cause damage to the gastrointestinal mucosa via several mechanisms, including the topical irritating effect of these drugs on the epithelium, impairment of the barrier properties of the mucosa, suppression of gastric prostaglandin synthesis, reduction of gastric mucosal blood flow and interference with the repair of superficial injury. ${ }^{8}$ The presence of acid in gastrie lumen also contributes to the pathogenesis of NSAID-induced ulcers and bleeding by impairing the restitution process, interfering with hemostasis and inactivating several growth factors that are important in mucosal defense and repair.

There are a lot of reports on NSAID-related gastric abnormalities which we call NSAID gastropathy, but there were very few reports on NSAID enteropathy which concern duodenal and jejunal part of intestine. ${ }^{9,10}$ The clinical symptoms of NSAID enteropathy are abdominal pain, diarrhea (acute and chronic), bleeding etc. In this study we studied the endoscopical abnormalities of NSAID-enteropathy as one of the NSAID's side effects.

\section{METHODS}

Osteoarthritic or rheumatoid patients with the age above 15 years old who were taking NSAID drugs (piroxicam and others), new or chronic users in the Division of Gastroenterology and Rheumatology, Department of Internal Medicine, University of Indonesia/ Cipto Mangunkusumo Hospital from January - June 2000 (6 months) were included in this study.

All of the patients underwent duodeno-jejunoscopy by the author of this study. Blood coagulation tests were performed before duodeno-jejunoscopy. We used the Olympus PCF-10 pediatric colonoscope for the examination. Patients were excluded if not cooperative, having a contraindication for upper gastrointestinal endoscopy examination or there was active bleeding or other causes like infection / inflammation.

The endoscopical appearances of NSAID-enterogastropathy were evaluated with personal scoring system, a modification of the Indonesian and Lanza scoring system. ${ }^{11,12}$ The endoscopic appearance of the NSAID entero-gastropathy were hyperemia, erosion and ulcer. Hyperemia was graded as normal, mild, moderate and severe. Erosion was graded as normal (no erosion), mild (less than 10 erosions), moderate (10-20 erosions) and severe (more than 20 erosions). Endoscopic grading were made qualitatively as normal mucosa, mild (mild hyperemia and/or mild erosion), moderate (moderate hyperemia and/or moderate erosion), and severe (severe hyperemia and/or severe erosion and/or ulcer).

The dyspeptic symptoms were also graded with a personal scoring system, a modification of Indonesian scoring system and Talley system. ${ }^{12,13}$ The dyspeptic symptoms were epigastric pain, nausea, vomiting, bloating, and anorexia. The grading system was made quantitatively as none (0), mild (1-5), moderate (6-10), severe (11-15). Epigastric pain: 0 (none); 1 (mild) if the pain was rare, not severe, 1-2 x/day and absent if the patient did not think about the symptom; 2 (moderate) if the pain occurred more than 2x/day, clearly, but did not disturb the daily activity; 3 (severe) if the pain occurred continuously, disturbed the daily activity or bedrest was needed to relieve the symptom. Nausea: 0 (none), 1 (mild) if it occurred 1-2 $\mathrm{x} /$ day absent if the patient did not think about the symptom; 2 (moderate) if it occurred more than $2 x /$ day, clearly, did not disturb the daily activity; 3 (severe) if occurred continuously and disturbed the daily activity. Vomiting: 0 (none); 1 (mild) if occurred $1 \mathrm{x} /$ day, did not disturb the daily activity, 2 (moderate) if occurred 2-3x/day, disturbed the daily activity, 3 (severe) if occurred more than $4 x /$ day and bedrest was needed. Anorexia: 0 (none), 1 (mild) if the patient still had appetite and more than half the daily requirement of the food was eaten; 2 (moderate) if the patient still had appetite but the food eaten was less than a quarter of the daily requirement; 3 (severe) if the patient had no appetite at all. Bloating: 0 (none), 1 (mild) if the patient felt bloated, but no meteorismus on physical examination; 2 (moderate) if the patient felt bloated and there was meteorismus on physical examination; 3 (severe) if the patient felt bloated and there was shortness of breath.

The data were analyzed using chi-square or Fisher test.

\section{RESULTS}

Thirty eight of 50 patients with NSAID consumption were examined (37 piroxicam and 1 acetyl salicylate). The following table shows the characteristics of the patients and their frequency. 
Table 1. Characteristics of patients

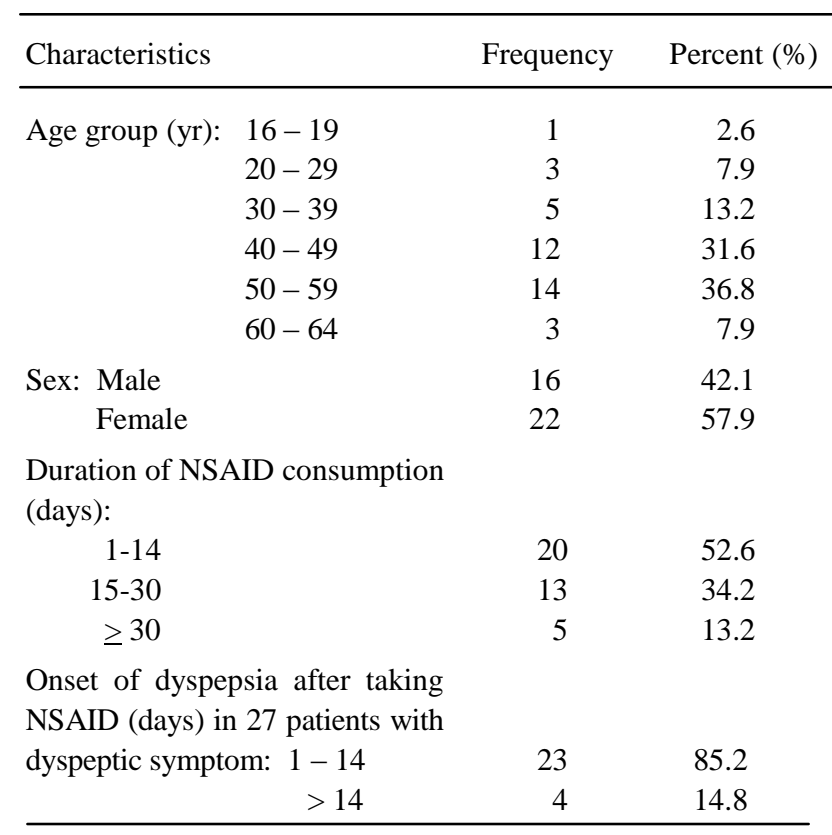

The youngest of the patients was 16 years old and the oldest was 64 years old (Table 1). The complaints were dyspepsia in 27 patients $(71.1 \%)$ and diarrhea in 3 patients $(7.9 \%)$. Most patients sufferred from mild dyspepsia (63.2\%) (Table 2). Twenty three (85.2\%) patients complained of dyspeptic symptom within 1-14 days after taking the NSAID and 4 (14.8\%) patients complained the dyspeptic symptom after more than 14 days of NSAID consumption. Twenty patients $(52.6 \%)$ had already consumed the NSAID between 1-14 days. There were nonbloody-non steatorrhea diarrhea complaints in 3 cases. Chronic diarrhea was observed in two patients, in which one had diarrhea lasting for 3 weeks and the other had diarrhea lasting for 4 weeks. One patient had acute diarrhea for only 1 week (Table 2).

Table 2. Symptoms of patients

\begin{tabular}{lcc}
\hline Symptoms & Frequency & Percent $(\%)$ \\
\hline Dyspepsia & & \\
Grade : None & 11 & 28.9 \\
Mild & 24 & 63.2 \\
Moderate & 2 & 5.3 \\
Severe & 1 & 2.6 \\
Diarrhea: No & 35 & 92.1 \\
Yes & 3 & 7.9 \\
\hline
\end{tabular}

Table 3. Endoscopic appearances of NSAID gastropathy and NSAID enteropathy

\begin{tabular}{|c|c|c|c|}
\hline \multicolumn{2}{|c|}{ Endoscopic appearances } & Frequency & Percent $(\%)$ \\
\hline \multicolumn{4}{|l|}{ Stomach: } \\
\hline \multirow[t]{4}{*}{ Hyperemia } & : None & 0 & 0.0 \\
\hline & Mild & 17 & 44.7 \\
\hline & Moderate & 20 & 52.6 \\
\hline & Severe & 1 & 2.6 \\
\hline \multirow[t]{4}{*}{ Erosion } & : None & 1 & 2.6 \\
\hline & Mild & 18 & 47.4 \\
\hline & Moderate & 7 & 18.4 \\
\hline & Severe & 12 & 31.6 \\
\hline \multirow[t]{2}{*}{ Ulcer } & No & 28 & 73.7 \\
\hline & Yes & 10 & 26.3 \\
\hline \multicolumn{2}{|c|}{ Grade of gastropathy : Normal } & 0 & 0.0 \\
\hline \multicolumn{2}{|c|}{ Mild } & 12 & 31.6 \\
\hline \multirow{2}{*}{\multicolumn{2}{|c|}{$\begin{array}{l}\text { Moderate } \\
\text { Severe }\end{array}$}} & 14 & 36.8 \\
\hline & & 12 & 31.6 \\
\hline \multicolumn{4}{|c|}{ Duodenal bulb: } \\
\hline \multicolumn{2}{|c|}{ Hyperemia : None } & 8 & 21.1 \\
\hline \multicolumn{2}{|c|}{ Mild } & 27 & 71.1 \\
\hline \multicolumn{2}{|r|}{ Moderate } & 3 & 7.9 \\
\hline \multirow{2}{*}{ Erosion } & Severe & 0 & 0.0 \\
\hline & : None & 23 & 60.5 \\
\hline & Mild & 14 & 36.8 \\
\hline & Moderate & 1 & 2.6 \\
\hline & Severe & 0 & 0.0 \\
\hline \multirow[t]{2}{*}{ Ulcer } & : No & 35 & 92.1 \\
\hline & Yes & 3 & 7.9 \\
\hline \multicolumn{2}{|c|}{ Grade of duodenopathy : Normal } & 8 & 21.1 \\
\hline & Mild & 25 & 65.8 \\
\hline & Moderate & 2 & 5.3 \\
\hline & Severe & 3 & 7.9 \\
\hline Descending & art of duodenum: & & \\
\hline Hyperemia & : None & 27 & 71.1 \\
\hline & Mild & 11 & 28.9 \\
\hline & Moderate & 0 & 0.0 \\
\hline & Severe & 0 & 0.0 \\
\hline Erosion & None & 32 & 84.2 \\
\hline & Mild & 6 & 15.8 \\
\hline & Moderate & 0 & 0.0 \\
\hline & Severe & 0 & 0.0 \\
\hline Ulcer & : No & 37 & 97.4 \\
\hline & Yes & 1 & 2.6 \\
\hline Grade of duo & lenopathy : Normal & 26 & 68.4 \\
\hline & Mild & 11 & 28.9 \\
\hline & Moderate & 0 & 0.0 \\
\hline & Severe & 1 & 2.6 \\
\hline Jejunum: & & & \\
\hline Hyperemia & : None & 35 & 92.1 \\
\hline & Mild & 2 & 5.3 \\
\hline & Moderate & 1 & 2.6 \\
\hline & Severe & 0 & 0.0 \\
\hline Erosion & : None & 37 & 97.4 \\
\hline & Mild & 0 & 0.0 \\
\hline & Moderate & 0 & 0.0 \\
\hline & Severe & 1 & 2.6 \\
\hline Ulcer & : No & 38 & 100.0 \\
\hline & Yes & 0 & 0.0 \\
\hline Grade of jeju & opathy : Normal & 35 & 92.1 \\
\hline & Mild & 2 & 5.3 \\
\hline & Moderate & 0 & 0.0 \\
\hline & Severe & 1 & 2.6 \\
\hline
\end{tabular}


Abnormalities compatible with NSAID enteropathy were seen in the duodenal bulb, in $30(79 \%)$ of the patients. There were $30(79 \%)$ cases of hyperemia, 15 $(39.5 \%)$ cases of erosion and $3(7.9 \%)$ cases of ulcer. In the second part (descending part) of the duodenum we found $12(31.6 \%)$ NSAID enteropathy appearances. There were $11(28.9 \%)$ cases of hyperemia, $6(15.8 \%)$ cases of erosion and $1(2.6 \%)$ case of ulcer. In the jejunum, we found $3(7.9 \%)$ NSAID enteropathy appearances. There were 3 (7.9\%) cases of hyperemia, 1 (2.6\%) case of erosion and no cases of ulcer. The NSAID gastropathy appearances were observed in $38(100 \%)$ cases (Table 3).

The existence of NSAID enteropathy appearances was not correlated with the existence of NSAID gastropathy appearances statistically $(\mathrm{p}>0.05)$ (see table 4$)$. The endoscopic NSAID enteropathy appearances were also not correlated with the clinical dyspeptic symptom $(\mathrm{p}>0.05)$.

\section{DISCUSSION}

The capability of nonsteroidal anti inflammatory drugs (NSAIDs) to damage the gastrointestinal mucosa has already been demonstrated in healthy subjects and in patients with arthritis and other musculoskeletal diseases. ${ }^{1-11,14-18}$

The data from this study shows the side effects of NSAID in stomach, duodenum and jejunum. All of the patients $(100 \%)$ were found to have NSAID gastropathy endoscopically, in which hyperemia $100 \%$, erosions $97.4 \%$ and ulcer $26.3 \%$ were seen. In the duodenum and jejunum the endoscopic abnormalities are less than in the stomach. NSAID duodenopathy was found in $79 \%$ endoscopically, as manifested by hyperemia 79\%, erosions $39.5 \%$ and ulcer $7.9 \%$. Endoscopically, NSAID jejunopathy was found in $7.9 \%$, as manifested by hyperemia $7.9 \%$, erosions $2.6 \%$. These findings were comparable to other previous reports. ${ }^{14-18}$

The most frequent age group was 50-59 years old, this was the same as in other reports. ${ }^{19,20}$

The use of NSAIDs doubled the risk of dyspepsia and heartburn in subjects $\geq 65$ years of age. ${ }^{19}$ In this study we found that only $71.1 \%$ of the patients had dyspeptic symptoms and the symptom did not correlate with the age $(\mathrm{p}>0.05)$.

Table 4. The correlation between NSAID-enteropathy and NSAID-gastropathy or dyspeptic symptom

\begin{tabular}{|c|c|c|c|c|c|c|c|c|c|c|}
\hline \multirow{9}{*}{$\begin{array}{l}\text { NSAID } \\
\text { Enteropathy } \\
\text { appearance }\end{array}$} & \multicolumn{4}{|c|}{ NSAID Gastropathy appearance } & \multirow[t]{9}{*}{$\mathrm{p}$-value } & \multicolumn{4}{|c|}{ Dyspeptic symptom } & \multirow[t]{9}{*}{ p-value } \\
\hline & $\mathrm{N}$ & $\mathrm{M}$ & M & $\mathrm{S}$ & & $\mathrm{N}$ & M & M & $\mathrm{S}$ & \\
\hline & o & $\mathrm{i}$ & o & $\mathrm{e}$ & & o & i & o & $\mathrm{e}$ & \\
\hline & $\mathrm{r}$ & 1 & d & $\mathrm{v}$ & & $\mathrm{r}$ & 1 & d & $\mathrm{v}$ & \\
\hline & $\mathrm{m}$ & $\mathrm{d}$ & $\mathrm{e}$ & $\mathrm{e}$ & & $\mathrm{m}$ & $\mathrm{d}$ & $\mathrm{e}$ & $\mathrm{e}$ & \\
\hline & $\mathrm{a}$ & & $r$ & $\mathrm{r}$ & & $\mathrm{a}$ & & $\mathrm{r}$ & $\mathrm{r}$ & \\
\hline & 1 & & $\mathrm{a}$ & $\mathrm{e}$ & & 1 & & $\mathrm{a}$ & $\mathrm{e}$ & \\
\hline & & & $\mathrm{t}$ & & & & & $\mathrm{t}$ & & \\
\hline & & & $\mathrm{e}$ & & & & & $\mathrm{e}$ & & \\
\hline \multicolumn{11}{|l|}{$\begin{array}{l}\text { 1. Duodenal } \\
\text { bulb: }\end{array}$} \\
\hline Normal & 0 & 4 & 3 & 1 & 0.39 & 2 & 5 & 0 & 1 & 0.09 \\
\hline Mild & 0 & 7 & 10 & 8 & & 7 & 17 & 1 & 1 & \\
\hline Moderate & 0 & 0 & 0 & 2 & & 0 & 1 & 1 & 0 & \\
\hline Severe & 0 & 1 & 1 & 1 & & 2 & 1 & 0 & 0 & \\
\hline \multicolumn{11}{|l|}{$\begin{array}{l}\text { 2. Descending } \\
\text { duodenum: }\end{array}$} \\
\hline Normal & 0 & 8 & 10 & 8 & 0.70 & 7 & 17 & 1 & 1 & 0.76 \\
\hline Mild & 0 & 4 & 3 & 4 & & 3 & 7 & 1 & 0 & \\
\hline Moderate & 0 & 0 & 0 & 0 & & 0 & 0 & 0 & 0 & \\
\hline Severe & 0 & 0 & 1 & 0 & & 1 & 0 & 0 & 0 & \\
\hline \multicolumn{11}{|l|}{ 3. Jejunum: } \\
\hline Normal & 0 & 11 & 14 & 10 & 0.47 & 10 & 22 & 2 & 1 & 0.72 \\
\hline Mild & 0 & 1 & 0 & 1 & & 0 & 2 & 0 & 0 & \\
\hline Moderate & 0 & 0 & 0 & 0 & & 0 & 0 & 0 & 0 & \\
\hline Severe & 0 & 0 & 0 & 1 & & 1 & 0 & 0 & 0 & \\
\hline
\end{tabular}


The effect of ethnicity of this study was very subjective, depending on the location where the study was conducted. This study was conducted in Java Island in Indonesia, so the most frequent ethnic group was Javanese. A study reported that white people consumed NSAID more frequently. ${ }^{20}$

Most frequently, the patient was female, this was in accordance with other previous reports. ${ }^{1-4,20}$

The most frequent duration of NSAID consumption was 1-14 days. A previous study reported that the risk of GI complications was highest in the first months of NSAID use, ${ }^{9,10,19}$ that was why in this study the patients had abnormalities in their gastrointestinal tract, $100 \%$ in the stomach, $79 \%$ in the duodenum endoscopically. However, another study reported that the cumulative incidence of gastroduodenal ulcers with the use of traditional NSAIDs was as high as 25$30 \%$ at 3 months and $45 \%$ at 6 months. ${ }^{19}$

There are only a few studies which reported the symptom of diarrhea due to NSAID. In this study we found $7.9 \%$ of the patients suffered from diarrhea, in which $2 / 3$ of the patients got chronic diarrhea that lasted for 3 weeks. After the NSAID was stopped, the diarrhea stopped too. This study showed that we should always keep in mind that diarrhea could be a complication of NSAID.

\section{CONCLUSION}

The most frequent abnormal endoscopical appearances in NSAID-enteropathy was hyperemia. The most frequent site of NSAID-enteropathy abnormal findings was in the duodenal bulb.

\section{REFERENCES}

1. Hawkey CJ. Management of gastroduodenal ulcers caused by non-steroidal anti-inflammatory drugs. Bailliere's Clinical Gastroenterology 2000; 14(1): 173-92.

2. Douthwaite AH \& Lintott SAM. Gastroscopic observation of the effects of aspirin and certain other substances on the stomach. Lancet 1938; 2: 1222-5.

3. Walt R, Katschinski B, Logan R, Ashley J, Langman M. Rising frequency of ulcer perforation in elderly people in the United Kingdom. Lancet 1986; I: 489-92.

4. Hawkey CJ. Non-steroidal anti-inflammatory drugs and ulcers: facts and figures multiply, but do they add up? BMJ 1990; 3000:278-84.
5. Henry D, Lim LL, Garcia Rodriguez LA, Perez Gutthann S, Carson JL, Griffin M et.al. The ability in risk of gastrointestinal complications with individual non-steroidal anti-inflammatory drugs: results of a collaborative metaanalysis. BMJ 1996; 312: 1563-6.

6. Singh G, Ramey DR, Morfeld D, Shi H, Hatoum HT, Fries JF. Gastrointestinal tract complications of nonsteroidal anti-inflammatory drug treatment in rheumatoid arthritis. A prospective observation cohort study. Arch Intern Med 1996; 156: 1530-6.

7. Bloom BS. Direct medical costs of disease and gastrointestinal side effects during treatment of arthritis. Am J Med 1988; 83(suppl 2A): 20-4.

8. Wallace Jl. How do NSAIDs cause ulcer disease?. Bailliere's Clinical Gastroenterology 2000; 14(1): 147-59.

9. Lanas A. Prevention and treatment of non-steroidal antiinflammatory drug gastroenteropathy. Rev Gastroenterol Mex 2004;69: 251-60.

10. Graham DY, Opekun AR, Willingham FF, Qureshi WA. Clin Gastroenterol Hepatol 2005; 3: 55-9.

11. Lanza FL, Graham DY, Davis RE. Endoscopic comparison of cimetidine and sucralfate for prevention of Naproxeninduced acute gastroduodenal injury - Effect of scoring method. Dig Dis Sci 1990;35(12): 1494-9.

12. Harsono. Gastritis: Suatu hubungan klinis dengan endoskopi dan patologi anatomi. Karya tulis akhir untuk mencapai sebutan spesialis-I Penyakit Dalam (Unpublished paper). Skripsi akhir PPDS Bag.I.Penyakit Dalam FKUI/RSCM. Jakarta1987.

13. Talley NJ,McNeil D, Piper DW. Discriminant value of dyspeptic symptoms: a study of the clinical presentation of 221 patients with dyspepsia of unknown cause, peptic ulceration, and cholelithiasis. Gut 1987;28: 40-6.

14. Bjarnason I, Price AB, Zanelli G, Smethurst P, Burke M, Gumpel JM et al. Clinicopathological features of Nonsteroidal Antiinflammatory Drug-Induced small intestinal strictures. Gastroenterology 1988;94:1070-4

15. Bjarnason I, Hayllar J, Macpherson AJ, Russell AS. Side effects of Nonsteroidal Anti-inflammatory Drugs on the small and large intestine in humans. Gastroenterology 1993;104:1832-47.

16. Kurahara K, Matsumoto T, Iida M, Honda K, Yao T, Fujishima M. Clinical and endoscopic features of Nonsteroidal Anti-Inflammatory Drug-Induced Colonic Ulcerations. Am J Gastroenterol 2001;96:473-80.

17. Puspok A, Kiener H-P, Oberhuber B. NSAID ColitisResolving a diagnostic dilemma?. Dis Colon Rectum 2000;43:685-91

18. Tibble JA, Sigthorsson G, Foster R \& Bjarnason I. Comparison of the intestinal toxicity of Celecoxib, a selective cox-2 inhibitor, and indomethacin in the experimental rat. Scand J Gastroenterol 2000; 8 :802-7.

19. Laine L. Approaches to Nonsteroidal Anti-inflammatory Drug use in the high-risk patient. Gastroenterology 2001;120:594-606.

20. Agrawal NM, Campbell DR, Safdi MA, Lukasik NL, Huang B, Haber MM. Superiority of Lansoprazole vs Ranitidine in Healing Nonsteroidal Anti-inflammatory Drug-Associated Gastric ulcers. Arch Intern Med 2000; 160:1455-61. 